\title{
Lumen
}

Selected Proceedings from the Canadian Society for Eighteenth-Century Studies

\section{Indigenes / Exoticism: A Response}

\section{Nicholas Hudson}

Volume 24, 2005

Indigenes and Exoticism

Indigènes et exotisme

URI : https://id.erudit.org/iderudit/1012182ar

DOI : https://doi.org/10.7202/1012182ar

Aller au sommaire du numéro

Éditeur(s)

Canadian Society for Eighteenth-Century Studies / Société canadienne d'étude du dix-huitième siècle

\section{ISSN}

1209-3696 (imprimé)

1927-8284 (numérique)

Découvrir la revue

Citer cet article

Hudson, N. (2005). Indigenes / Exoticism: A Response. Lumen, 24, 165-171.

https://doi.org/10.7202/1012182ar

Copyright (c) Canadian Society for Eighteenth-Century Studies / Sociéte canadienne d'étude du dix-huitième siècle, 2005
Ce document est protégé par la loi sur le droit d'auteur. L'utilisation des services d'Érudit (y compris la reproduction) est assujettie à sa politique d'utilisation que vous pouvez consulter en ligne.

https://apropos.erudit.org/fr/usagers/politique-dutilisation/ 


\section{Indigenes / Exoticism: A Response ${ }^{1}$}

Only bad conferences confirm what everyone thought before. A good conference provides new insights, challenging, complicating, and even overturning the received ideas of those who attend. On the evidence of the papers collected in this volume by Alex Dick and Jo-Ann McEachern, 'Indigenes and Exoticism / Indigènes et Exotisme,' the 2003 meeting of the Canadian Society for Eighteenth-Century Studies was just such a success. The essays here have the required effect of undercutting, complicating, and, as the result, enlarging our understanding of the twinned concepts presented in the conference title. And while the theoretical and political interrelations between indigenes and exoticism hardly constitute a 'field of study,' at least at the moment, this collection suggests what sort of questions, problems, and debates such a field might encompass.

The foundational question concerns what 'indigenous' and 'exotic' actually mean. They are both relatively recent terms. 'Exoticism' is a nineteenth-century word, as pointed out by Pierre Berthiaume; 'indigene' used to refer only to plants, but has still more recently been extended in post-colonial scholarship to people. ${ }^{2}$ The nexus of their relationship obviously lies in the prefixes 'ex'/'in,' for these words denote assumptions about what is external and what is internal. But is this relationship entirely clear or stable? In certain texts, the difference between 'in' and 'out' seems pellucid and fixed. Catherine Gallouët's 'Sade, noir et blanc: Afrique et Africains dans Aline et Valcour' presents, as the title implies, a text in which there is absolute opposition between the external and internal: with his wonted lack of subtlety, Sade can imagine black Africans only as cannibals, and therefore beyond any

1 Thank you to the editors Alex and Jo-Ann for asking me to write this response. I have written about the 2003 conference elsewhere under the title 'In and Out of Hegemony: Academic Conferences and the 'Public Sphere,' Literature Compass ('Viewpoints' section, http://www.literature-compass.com/18thcentury/view).

2 'Les Lettres Persanes Ou I.'exotisme Sans L'exotisme,' 1. 
possibility of sympathy or even interest. Significantly, there is nothing 'exotic' about Sade's Africans. In his black and white universe, these people cannot be 'exotic' because they are too external, too outside a normative frame of reference. Sade spent his career as a writer dwelling pruriently over the difference between in and out, over what was 'natu$\mathrm{ral}^{\prime}$ and what constituted, in his work, the unusually narrow space of the obscenely 'unnatural.' But his legacy, while perhaps occasionally 'exotic,' is not often so. The case of Sade suggests that, contrary to the logic of its etymology, 'exoticism' cannot denote absolute alterity.

In other essays, 'exoticism' seems an impossible category, though for different reasons. Beatriz de Alba-Koch presents the historian Francisco Javier Clavijero as capable of a kind of non-racist sympathy for the fate of American indigenes not displayed by European historians of the New World like de Pauw, Raynal and Robertson who (to vastly different degrees, I would urge) shared Sade's tendency to construct the nonEuropean specimen as an absolute 'Other.' Clavijero, the historian who first named the people of central Mexico 'Aztecs,' found them tragic rather than exotic because he himself was a native-born Mexican, a Jesuit-trained Creole. For the same kind of reason, however, a man so imbued in the European and Christian tradition could not view the conquering Spaniards as absolutely evil, much less 'exotic.' Though discomforted by the conquest, he ascribed it piously to the decree of Providence. In short, if Clavijero could not find exoticism anywhere in this event, it was for reasons precisely opposite to those that made Sade impervious to the category: Clavijero was too inside the opposing cultures. He was too doubly 'indigenous.'

Similarly, the 'exotic' has virtually no place in Denis Diderot's ethnographic essays in the Encyclopédie, though this absence must be explained in a very different way. As presented in Mitia Rioux-Beaulne's 'Aller-retour: fonction épistémologique et réflexive de l'altérité chez le Diderot de l'Encyclopédie,' Diderot's fear of dogmatism prescribed a program of intense doubt with regard to the reliability of any description of a non-European culture. His essays on ethnographic topics for the Encyclopédie set out the belief that all human cultures are shaped by a universally applicable set of human needs and desires. But Diderot insisted on the potentially unlimited range of cultural variation arising from these basic principles. While this outlook made certain ethnographical descriptions humanly preposterous (such as the story that in a certain African kingdom it was the highest honour to be eaten by the king), it simultaneously rendered all ethnographical descriptions provisional, for no point-of-view could or should deny the vast range of cultural diversity within such limits. Hence, Diderot stood at the opposite end from Sade on the horizon of French Enlightenment thought: 
Diderot cast doubt on the dogmatic exclusion of the Other with the same conviction that Sade perpetuated just this dogmatic exclusion. How striking, then, that both authors also seem so resistant to identifying the foreigner as 'exotic.' While, for Sade, the cannibalistic black African was too external to be exotic, for Diderot such separations between 'in' and 'out' could exist only in the most provisional and heuristic form.

The essays cited to this point suggest, in short, that the 'exotic' can exist neither where the division between indigenes and the non-indigenes is unbridgeable, nor where the very distinction between what is 'external' and what is 'internal' becomes untenable. Where, then, can the 'exotic' finally take root? The set of conditions for a real distinction between indigenes and exoticism begins to be glimpsed in the essays by Robert Merrett and Pierre Berthiame. Merrett's 'Daniel Defoe and Islam' mounts the case for Defoe's essential sympathy for the Islamic world as brave, chaste, and honest - the attitude of a merchant who spent competitive, yet profitable, periods of his life as a 'Turkey merchant' negotiating with Middle-Eastern business interests. In Merrett's reading, therefore, Roxana's seductive performance as a Turkish dancer in exotic costume is not a commentary on the decadence of the Orient (the normative Western image of the East, according to Edward Said) but is rather an exposure of an English society that indulges false images of the Eastern 'other' to facilitate the enjoyment of its own forbidden desires. From this point of view, therefore, the 'in' and the 'out' begin to become entangled. And this conflation is even more obvious in Pierre Berthiaume's 'Les Lettres persanes ou l'exotisme sans l'exotisme.' Like Beaulne's essay on Diderot, Berthiaume's essay suggests that the French Enlightenment's conviction in the universally 'human' cast a graying light over the coloured plumage of exoticism. In their letters, Montesquieu's Persians present the most potentially 'exotic' features of their world - their seraglios, their eunuchs - in a dryly functional way that reflects both the familiarity of indigenes with their own customs and the rationalistic, practical concerns of Montesquieu's French audience. Nevertheless, when the Persian travelers reach Paris, they do start to experience the sensation of being viewed as creatures descended from some far-off realm of the 'exotic.' As portrayed by Montesquieu, the gawking French spectators experience 'exoticism' as culturally self-affirming: they stare at the strangeness of the Persians because it confirms their own sense of normality. Yet, as Berthiaume emphasizes, the novel ironically undermines the possibility of founding one's identity on the creation of the Other, for he shows the Persians wondering back at the oddness of their spectators. 'Exoticism,' that is, deconstructs itself; the exchanged gaze of the Parisians and the Persians proves that all attempts to equate the 'indigenous' with the 'normal' are founded on the sands of subjectivity. 
In the essays by Merrett and Berthiaume, the 'exotic' begins to be glimpsed in a theoretical space where alterity is neither absolute nor endlessly uncertain. For Defoe the 'exotic' actually excuses the release of indigenous desires towards a figure disguised as the fictional Other; in Les lettres persanes the Persians belong within the ambit of human nature even from the perspective of the Parisians who stare at them. The 'exotic,' these essays suggest, is a paradoxical category where the 'external' is recognized as also 'internal' - a paradox, pace Diderot, founded on the belief that the distinction between 'inside' and 'outside' is not merely provisional. As shown by Kathryn Jones in "Curious Scotch Plants": Scotland as the Exotic in the Early Edinburgh Physic Garden,' Scottish plants were prized as 'exotic' because Scotland itself lay at an exotically remote distance in the imagination of non-Scots. That Scottish plants and, by extension, Scotland itself represented the 'exotic' in an attractive form (in contrast with the largely negative presentation of the 'exotic' in the essays by Merrett and Bertiaume) surely had something to do with the fact that Scotland was remote without being 'Other.' The Scottish academics who presided over the early Edinburgh physic garden were hardly the inhabitants of Sade's cannibalistic 'Butua,' and their exchange of Scottish exotics for exotics from elsewhere relativized alterity in a way (in contrast, again, with Berthiaume) that promoted aesthetic pleasure rather than existential irony.

Thus the exotic could be a source of pleasure, not merely of anxiety or hypocrisy - a fact of historical significance. Both English and French speakers have inherited the word 'exotic' in a form bursting with largely positive connotations - the result of a middle-rank social revolution that created the concept of 'harmless pleasure.' I quote this phrase as used by the conservative Samuel Johnson to describe the pleasures afforded by the modern English stage, ${ }^{3}$ hardly a place traditionally considered harmless or innocent. Yet the previously decadent space of the theatre had been domesticated by the nascent 'bourgeoisie' into a space suitable for the respectable citizen, if only with a certain uncomfortable self-consciousness. This domestication does not mean that the theatre lost its exotic allure as an entertainment that tested forms of behavior that were neither entirely foreign to the audience nor publicly accepted. For the 'exotic,' like the theatre, became an area for probing the increasingly ephemeral division between what was and what was not acceptable.

3 The remark is made in a eulogy to David Garrick in Lives of the English Poets, ed. G.B. Hill, 3 vols. (Oxford: Clarendon Press, 1905), 2:21. 
Homosexuality, particularly among men affecting conventionally female dress and roles, would seem well beyond the pale of the 'acceptable.' In the eighteenth century, the behavior of so-called 'Mollies' certainly verged on the Sadean realm of the excluded and unnatural. Yet what I found most interesting in Lauren Craig Stephens's Madoff Prize winning essay "Preternatural Pollutions": Nature, Culture, and SameSex Desire in Edward Ward's "Of the Mollies Club,"' was its suggestions that Molly culture had become disturbingly, and even exotically, internalized. Most obviously, Ned Ward had to assume that the Mollies were fully heterosexual males in order to protect his own insistence that their sodomitic and cross-dressing behavior was 'unnatural.' And if Ward generally encouraged readers to share his expressed revulsion from the Mollies, at some point his response was the kind of 'wonder and amusement $^{4}$ associated with the 'exotic.' Ward was a shrewdly successful judge of the reading public's taste for the exotically outlandish: in important respects, 'Of the Mollies Club' belongs to the same genre as his popular proto-novel, The London Spy, a serial publication that carries its fascinated reader through the underbelly of a nocturnal world not far geographically from the monuments of English respectability. Ward's Mollies are not just disgusting 'Others'; they are absorbing, even guiltily enticing neighbours.

Indeed, the 'exotic' is perhaps never entirely estranged from what indigenes, European or otherwise, consider wrong or outlandish. But the externality of exotic objects must, it seems, also possess some paradoxical relation to indigeneity. Even more obviously than Stephens's "Preternatural Pollutions,"' Laurence Mall's 'Femmes en public et femmes publiques dans le Tableau de Paris de Mercier' explores the ambivalent territory between what is morally troubling (women of the upper and middle ranks who frequent the streets like 'prostitutes,' decked in finery) and what is both geographically and morally normative (the coarsely innocent public women at the fish or vegetable stall). For Mercier, the very ambivalence of these well-dressed public women lends them an exotic allure that is at once confounded, guilty and guiltless: ' Les comportements et habitudes des femmes en public, leurs jeux de physionomie, leur démarche, leurs vêtements, leurs lieux de promenades et de travail, leurs moyens de transport, tout cela fascine Mercier. Cette fascination peut être d'ordre esthétique; la femme-spectacle, parée et offerte à la vue stimule un imaginaire érotisé où la pure jouissance du 
regard exclut toute condemnation.' Yet, for all his bourgeois readiness to take moral offence, as codified by Rousseau, Mercier separates the exotic charm of these economically stable women from the alien desperation of the common prostitute. Rather than enticed by the prostitute, 'Mercier est souvent horrifië par le sort des femmes les plus pauvres, par les prostituées lamentables et désespérées ou ce qu'il appelle 'le libertinage de détresse marchant dans les rues fangeuses. ${ }^{\prime 5}$ In short, the sort of exotic Parisian woman who simultaneously disturbs and seduces Mercier can be identified neither with the utterly respectable (and unremarkable) band of bourgeois women who take their well-chaperoned turn in the Jardins de Luxembourg, nor with the desperately impoverished girl on her lonely stroll through the Marais. The exotically public woman walks - geographically, socially, morally - somewhere in between.

The conference title of 'Indigenes and Exoticism,' this essay suggests, harbours a paradox, even an aporia. The melting of the division between what is 'in' and 'out' is even more strongly sensed in Servanne Woodward's 'Les Amérindiens dans les Mémoires de la Marquise de La Tour du Pin.' The marquise de La Tour du Pin, post-revolutionary aristocrat on a foreign continent, nonetheless finds personal and ideological sustenance in identification with native North Americans. Their alternating activities of hunting and warfare invited pleasing comparisons with an idealized French chevalier, particularly as they were viewed through the rosy European lens of 'the noble savage.' The Marquise found herself reaffirmed: 'la marquise régénère son illustre condition dans sa proximité aux Améridiniens.' She even chopped away in the kitchen with a native axe to the approving laughter of dignified guests like Tallyrand, who observed that 'On ne peut embrocher un gigot avec plus de majesté.' But this identification worked because it was always only partial. The nobility of these aboriginals was not feudal, like the marquise's, but belonged rather to 'L'Age d'Or.' Their lifestyle, such as their frequent nudity, set them outside 'civilization' in a place and time that the marquise could view fondly while retaining a sense of difference. And this only superficial identification with the 'noble savage' meant that the marquise did not hesitate to conspire with American officials to deprive local Oneidas of their land when it was finally in her interest.

Hence, in Woodward's essay, the paradoxical interrelation of the indigenous and the exotic becomes fully apparent. The American indi- 
genes are exotic from the marquise's point-of-view because they are neither fully Other (the marquise partially identifies with them) nor fully the same (the marquise never forgets their difference from her). The marquise, nominal foreigner, pretends to be the native American indigene in her kitchen, yet her ultimate allegiance to 'la caste gouvernante ${ }^{6}$ of New York State makes clear that she considers herself the true 'indigene.' Across these boundaries flits the 'exotic.' One recalls the two paintings by George Romney that served as icons for the conference one of the Mohawk leader Joseph Brant dressed in both his nation's headdress and portions of a British military uniform, the other of Edward Wortley Montagu attired like a Turk though he is decidedly pale skinned. In these pictures, the paradoxical pleasure of the exotic is experienced in the state of being both 'in' and 'out' at the same time.

What, then, is the place of the exotic in our political discourse about alterity in all its forms - ethnic, sexual, and so forth? The behaviour of the Marquise de La Tour du Pin suggests that exoticizing the Other can be patronizing, superficial, and even politically devious. Similarly, Roxana's exotic 'Turkish' dancing is both falsifying and hypocritical. Something similar could probably be said of certain infantalizing versions of chinoiserie or black-face portrayals of African Americans. Nevetheless, one also recalls that the absolute alterity that characterizes Sade's view of Africans is inherently demonizing and historically dangerous. In contrast, to the small extent that Montesquieu's Parisians and Persians can gaze at each other curiously as odd varieties of the same species, or that Mercier can feel a kind of uncomfortable pleasure at the sight of strolling middle-rank women, something has been achieved towards the acceptance and even pleasurable embracing of difference. Alterity, after all, is not an erasable category; it is only rarely that we can share Clavijero's advantage of having two identities at the same moment. Between usually divided identities, exotic pleasure can sometimes offer the experiment, l'expérience, of understanding the other as oneself.

\section{NICHOLAS HUDSON}

University of British Columbia 